\title{
Kronik ağrı nörofizyolojisi
}

\section{Neurophysiology of chronic pain}

\author{
Meltem Uyar ${ }^{1}$, İdris Köken²

\begin{abstract}
${ }^{1}$ Ege Üniversitesi Tıp Fakültesi Anesteziyoloji ve Reanimasyon Anabilim Dalı, Algoloji Bilim Dalı, Bornova, İzmir
\end{abstract} \\ ${ }^{2}$ Izmir Tepecik Eğitim ve Araştırma Hastanesi, Algoloji Bilim Dalı, Bornova, İzmir
}

Kronik ağrı, üç aydan uzun bir süredir var olan, iyileşme sürecinden bağımsız, beraberinde affektif, bilişsel ve motivasyonel bozuklukların da eşlik ettiği, fonksiyonel azalma ve yaşam kalitesinde bozulmaya yol açan, multimodal tedavi gerektiren maladaptif bir durumdur. Gerek nosiseptif, gerek nöropatik gerekse de mikst tipteki ağrılar kronikleşebilir. Ağrının kronikleşmesi, bir dizi moleküler ve hücresel süreç içerir. Uzamış inflamasyon, periferik sensitizasyon ve santral sensitizasyon, ağrı iletim ve işleme süreçlerini değiştirir. Kronik ağrının gelişmesine neden olan bu mekanizmalar sonuçta ağrının algılanma sürecinin değişmesine yol açar. Bu makalede ağrının kronikleşme sürecine neden olan mekanizmalar ele alınacaktır.

Anahtar sözcükler: kronik ağrı nörofizyolojisi
Chronic pain is a maladaptive condition which lasts longer than 3 months and accompanies with affective, cognitive and motivational disorders. It leads to decreased functions and deterioration in life quality, and requires a multimodal treatment. Nociceptive, neuropathic or mixed pain could be chronic. Chronic pain involves a series of molecular and cellular progressions. Prolonged inflammation, peripheral sensitization and central sensitization alter pain transmission and process. Therefore, these mechanisms that cause development of chronic pain lead to differences in the progress of pain signal reception. In this study, these mechanisms causing pain turn into a chronic state are reviewed.

Key words: neurophysiology of chronic pain

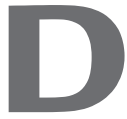

ünya Sağlık Örgütü tarafından ağrı, özellikle de kronik ağrı önemli bir halk sağlığı sorunu olarak kabul edilmiştir. ${ }^{[1]}$ Ağrının iyi tanımlanması, ağrıyı iyi anlamak, tanısının konması ve etkili tedavisinin yapılabilmesi açısından büyük önem taşımaktadır. ${ }^{[2]}$

IASP'nin tanımına göre ağrı, vücudun belli bir bölgesinden kaynaklanan, doku harabiyetine bağlı olan veya olmayan, kişinin geçmişteki deneyimleriyle ilgili, hoş olmayan bir emosyonel duyumdur. IASP'nin tanımından da anlaşılabileceği gibi ağrının subjektif ve psikolojik bir doğası da vardır. Ayrıca, ağrı deneyimi her zaman altta yatan bir doku hasarının varlığını da göstermez. ${ }^{[2]}$ Ağrı duyusu merkezi sinir sistemi aktivitesinin yanı sıra eş zamanlı olarak duyguların, düşüncelerin ve hatta inançların iç içe geçmesiyle şekillenen bir deneyimdir. ${ }^{[3]}$

Tüm duyular; dokunma, sıcaklık ve ayrıca ağrılı olabilecek zararlı ISı, mekanik ve kimyasal uyarılar, periferik sinirlerle spinal korda taşınır. Spinal kord bu uyarıları değerlendirir, amplifiye veya modifiye eder. Spinal kord ağrı duyusu için bir entegrasyon merkezidir. Medulla spinaliste işlenmiş bu uyarılar, çıkan yollar vasıtasıyla beyinde yer alan üst merkezlere iletilir. Somatosensöriyel korteks ağrının şiddetini ve lokalizasyonunu belirlerken, limbik yapılar bu deneyime affektif (korku, öfke gibi) ve kognitif özellikler katmasının yanı sıra otonomik değişikliklerin de ortaya çıkmasına neden olur (uyku veya iştah değişiklikleri gibi). Bu iki supraspinal yapıdan, spinal korda işlenmiş ağıı sinyalleri ağrıyı modüle eden inen yollar aracılığıyla geri döner (Şekil 1). ${ }^{[4-6]}$

Nosisepsiyon; vücudun bir bölgesindeki doku yaralanmasında uyarının özelleşmiş sinir uçları ile (nosiseptör) alınıp santral sinir sistemine götürülmesi, belirli bölge ve nöral yapılarda entegre edilmesi, bu zararlı tehdidin (noksiyus) algılanması, buna karşı fizyolojik, biyolojik ve psikolojik önlemlerin harekete geçirilmesidir. Nosisepsiyon, doku hasarı ile ağrının algılanması arasında oluşan karmaşık elektrokimyasal olayların

- İletişim adresi: Prof. Dr. Meltem Uyar, Ege Üniversitesi Tıp Fakültesi Anesteziyoloji ve Reanimasyon Anabilim Dalı, Algoloji Bilim Dalı, Bornova, İzmir Tel: 0232 - 3902157 e-posta: meltemuyar@gmail.com

- Geliș tarihi: 20 Șubat 2017 Kabul tarihi: 20 Șubat 2017 


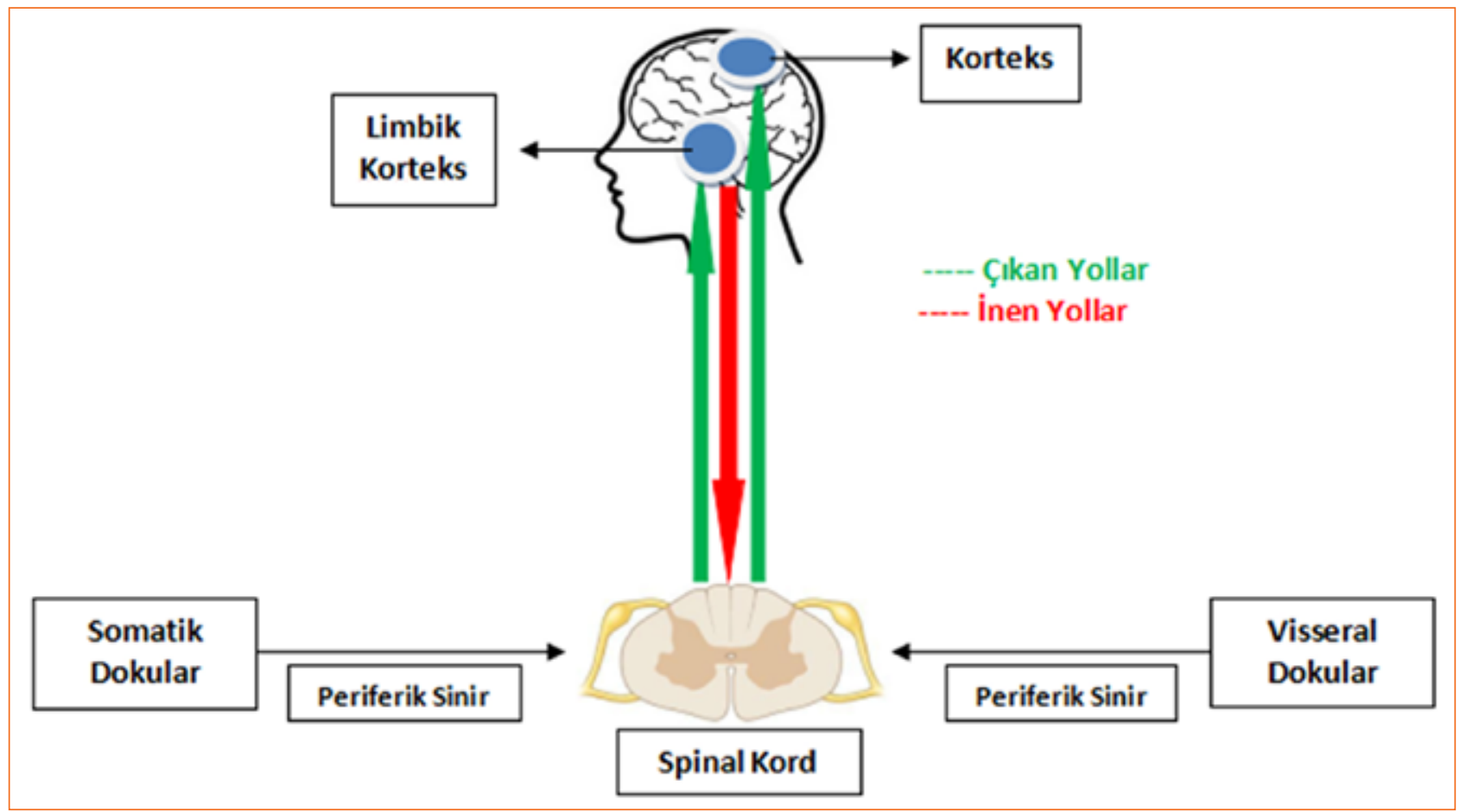

Şekil 1. Ağrı yolakları.

bir bütünüdür. Ağrı, nosisepsiyon içinde bir algılama olayıdır; travmatik veya noksiyus stimülasyona verilen nöral cevaptır. Nosiseptörlerden gelen tüm uyarılar ağrıyı oluşturur, fakat tüm ağrılar nosisepsiyondan kaynaklanmaz. ${ }^{[7,8]}$

Ağrı duyusu başlıca, ince miyelinli A delta ve miyelinsiz C sinir liflerinin serbest sinir sonlanmaları tarafindan algılanarak spinal korda taşınır. Bu yüzden, ağrı duyusuyla ilişkili olan bu liflere nosiseptör adı verilmektedir. A delta lifleri başlıca termal ve mekanik uyaranları taşırken, $C$ lifleri mekanik, kimyasal ve termal uyaranları taşır. $\mathrm{C}$ lifleri, neredeyse tüm ağrılı uyaran tiplerini taşımasından dolayı polimodal nosiseptörler adını alır. ${ }^{[9,10]}$

Nosiseptörler; cilt, kas, vissera, kemik gibi birçok yerde bulunur. Özelleşmiş bu duyusal nöronlardan glutamat gibi eksitatör nörotransmitterlerin salınması ağrıyı arttırıcı, GABA gibi inhibitör nörotransmitterlerin salınması ise ağrıyı azaltıcı yönde etki yapar. [11-13]

Somatik ve visseral yapıların ağrı duyusu, A-delta lifleri ile medulla spinaliste Lamina 1 ve 5'te, C lifleriyle Lamina 1 ve 2'de ikinci sıra nöronlarla sinaps yapar. Somatik yapılarda bulunan nosiseptörler mekanik, kimyasal ve termal uyaranlara karşı hassasken visseral yapılardaki nosiseptörler başlıca gerilme, iskemi ve distansiyona karşı hassastır. Visseral yapılardaki nosiseptör yoğunluğu somatik yapılara göre daha az olup somatosensöriyel kortekste temsili somatik yapıların aksine sınırlıdır. Visseral ağrı afferentlerine sempatik lifler eşlik eder; bu lifler T1-L2 seviyesinden medulla spinalisten çıkar. Komşu visseral yapılardan kalkan ağrılı impulslar aynı ikinci sıra spinal nöronda sinaps yapabildiği gibi (vissero-visseral konverjans), somatik yapı kaynaklı ağrı impulsları visseral yapılardan gelen ağrı impulslarıyla benzer şekilde aynı ikinci sıra spinal nöronda (vissero-somatik konverjans) sonlanabilir. Bu nedenlerle, visseral yapılardan kaynaklanan ağrıların somatik yapılardan kaynaklanan ağrılara kıyasla lokalizasyonu net değildir; daha yaygın bir alanda hissedilir ve otonomik bulgular eşlik edebilir. ${ }^{[14-16]}$

Spinal kord, periferiden gelen ağrı sinyallerini çıkan yollar vasıtasıyla üst merkezlere iletir. Kortekse ulaşan bu sinyaller, üst merkezlerde değerlendirildikten sonra beyin sapı yoluyla spinal korda geri dönerek ağrıyı kontrol eden inen yolları oluşturur. İnen yollar, noradrenalin, seratonin ve dopamin gibi monoaminleri kullandığı için monoaminerjik bir yolaktır. Bu yollar sadece ağrıyı azaltan özellikte olmayıp ağrıyı reseptör alt 


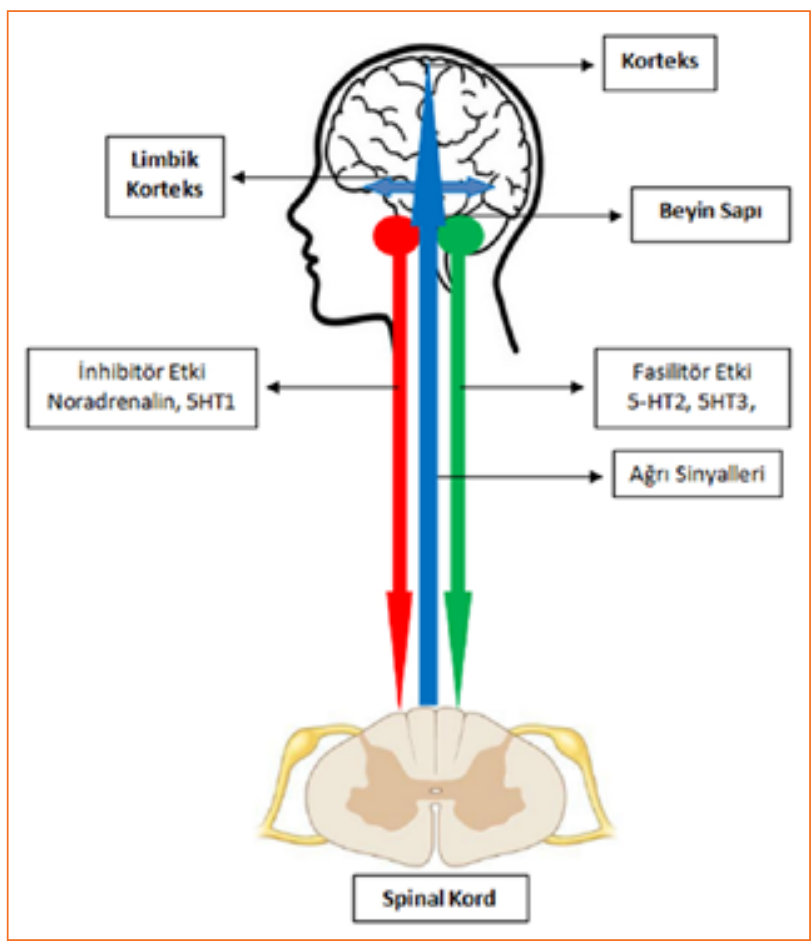

Şekil 2. Ağrının modülasyonu.

tipi ve baskın monoamin tipine göre arttırabilir de. Bu yüzden, bu yolak modülasyon yolağı olarak da adlandırılır. Örneğin; seratonin 5HT1 reseptörü üzerinden inhibitör etki sağlarken 5 HT2,3 üzerinden fasilitör etki gösterir. Noradrenalin ise pür inhibitör etkiye sahiptir (Şekil 2). ${ }^{[6,17]}$

Ağrının algılanması, ağrıya hassas nosiseptörlerin aktivasyonu veya hasar görmüş dokudan salınan mediyatörler tarafindan, medulla spinalise afferent transmisyon ve dorsal boynuz üzerinden yüksek merkezlere ileti aşamaları ile gerçekleşir. Ağrı; transdüksiyon, transmisyon, modülasyon ve persepsiyon olmak üzere dört aşamada algılanır. Transdüksiyon; nosiseptörlerde ağrılı uyaranın elektriksel aktiviteye dönüştürüldüğü aşamadır. Transmisyon; nosiseptif impulsun sinir sistemi boyunca iletilmesidir. Transmisyon esnasında, öncelikle primer sensöriyel afferent nöronlar elektriksel aktiviteyi spinal korda taşır. Bunu takiben, nosiseptif impulslar medulla spinalisten assendan ileti sistemi vasıtasıyla beyin sapı ve talamusa ulaştırılır. Son olarak, talamustan talamokortikal bağlantılarla somatosensöriyel kortekse projekte olur. Modülasyon; nosiseptif transmisyonun nöral etkenlerle modifiye olmasıdır. Persepsiyon ise bireyin psikolojisi ile etkileşimi ve subjektif emosyonel deneyimleri sonucu gelişen, uyarının algılandığı son aşamadır. ${ }^{[7,8]}$
Nosisepsiyondan sorumlu C lifleri, peptiderjikve nonpeptiderjik olmak üzere iki gruba ayrılır. Peptiderjik Tip $1 \mathrm{C}$ lifleri CGRP (kalsitonin geni ile ilişkili peptid) ve subtans $\mathrm{P}$ gibi peptidler içerir. Bu liflerden salgılanan peptidler, periferik sinirde veya çevrede istirahat halinde bulunan mast hücrelerini aktive ederek bu hücrelerden histamin salgılanmasına yol açar. Vazoaktif bir peptid olan histamin, lezyon bölgesinde kızarıklık, ödem ve deride hiperaljezi gibi lokal inflamasyon belirtilerine neden olur. Tip $2 \mathrm{C}$ lifleri ise, SP veya CGRP gibi peptidler taşımadıkları için, non-peptiderjik $C$ lifleri adını alır ve bu liflere ait dorsal root gangliyon nöronlarının santral uzantıları, lamina 2'nin iç tabakalarında bulunan internöronlarla bağlantı yaparak ağrı modülasyonunda rol oynar. C liflerinin yaklaşık \%10-20'si, normalde inaktif olan ve nosiseptif uyaranlara yanıt vermeyen sesssiz liflerdir. Sinir hasarı veya inflamasyon durumunda, sessiz $C$ lifleri de aktive olarak hiperaljezi gelişmesine katkıda bulunur. ${ }^{[18]}$

A-delta lifleri de, peptiderjik $C$ liflerine benzer şekilde, CGRP ve Substans $P$ gibi peptidler içerir. Bu liflerin büyük çoğunluğu, lamina 5'te yer alan WDR (Geniş Dinamik Alan) nöronlarında sonlanır. WDR nöronlarında ayrıca, yüzeyel dokunma duyusunu da taşıyan A-Beta lifleri de sonlanmaktadır. Bu sayede, WDR nöronları hem zararsız uyarılara hem de nosiseptif uyarılara yanıt vermektedir. Bu özellik, WDR nöronlarının afferent trafiği entegre etmesine ve uyarının yoğunluğunu modalitesinden bağımsız olarak düzenleyebilmesine olanak sağlar. ${ }^{[7,15]}$

Lamina 1'de bulunan ikinci duyusal nöronların aksonlarının çok az bir bölümü, lamina 5'teki ikinci duyusal nöronların aksonlarına katılır; bunu takiben, anterior kommissürden karşı tarafa geçer, spinal kord anterolateral kadranda yükselen spinotalamik traktusu oluşturur. Spinotalamik traktus, talamik nükleusun ventroposteriorunda somatotopik tabakada sonlanır. Buradaki hücrelerden, post-santral girustaki somatosensitif kortekse talamokortikal projeksiyonlarla aksonlar gitmekte ve noksiyus stimulusları taşımaktadır. Spinotalamik traktus, ağrının duyusal ayrımını sağlamaktadır. Lamina 1'de yer alan ikinci duyusal nöronların aksonlarının büyük bölümü, benzer şekilde spinal kord içerisinde karşı tarafa geçerek spinal kord anterolateral kadranda yükselen traktus spinomezensefalikusu oluşturur. Traktus spinomezensefalikus, medulla, pons ve mezensefalon gibi supraspinal merkezlerde bulunan periakuaduktal gri cevher (PAG) ile parabrakiyal nükleusta (PBN) sonlanır. Bunu takiben, bu bölgelerden de amigdala ve hipotalamusa giderek, korku, kaçınma, anksiyete gibi ağrıyla ilişkili emosyonel davranışlar, otonomik reaksiyonlar ve endojen olarak ağrıyı modüle eden yapıların aktivasyonunu sağlar (Şekil 3). ${ }^{[18]}$ 


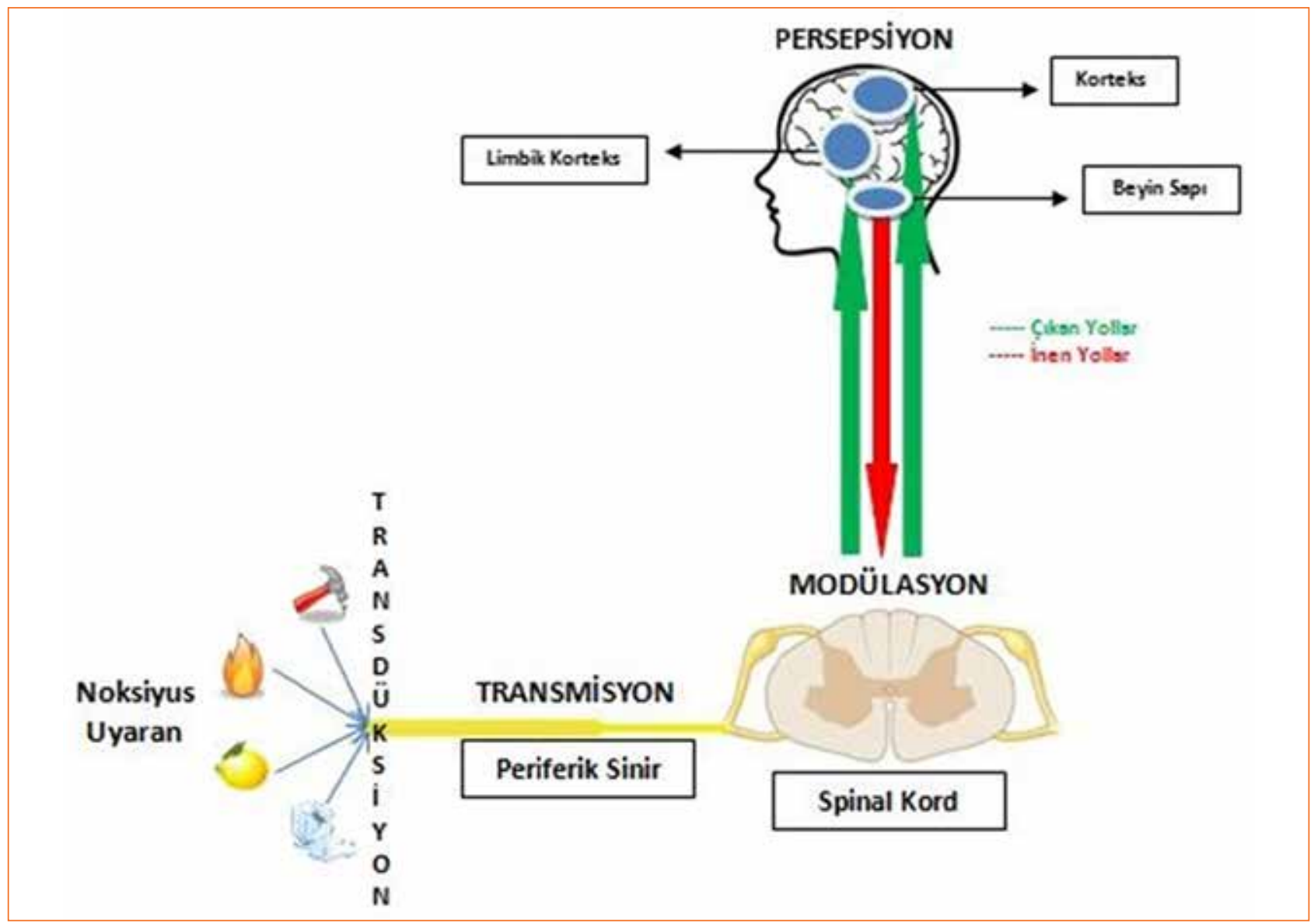

Şekil 3. Nosisepsiyon aşamaları.

Ağrı, homojen bir duyusal antite değildir. Genel olarak, hoş olmayan ve acıtan tüm duyumlar için ağrı denilmekteyse de; meydana geliş biçimi ve tutulan dokuya yönelik olarak başlıca nosiseptif ve nöropatik olmak üzere iki farklı ağrı tipi vardır. Nosiseptif ağrı, dokulardaki hasar sonucu ortaya çıkan ağrıdır; somatik veya visseral doku kaynaklı olabilir. Nöropatik ağıı ise somatosensöriyel sistemde lezyon veya hastalık sonucu ortaya çıkar. Periferik sinir sistemi tutulmuşsa periferik nöropatik ağrıdan; spinal kord veya beyin gibi merkezi yapılar tutulmuşsa santral nöropatik ağrıdan söz ederiz. Birçok ağının ise karışık nosiseptif ve nöropatik etiyolojisi vardır.

Nosiseptif ağrı, vücudun herhangi bir yerinde inflamasyon veya doku hasarı sonucunda gelişebilir. Hasarlı alanda immün hücrelerden salınan, CGRP, nörokinin $A$, histamin, bradikinin, substans $P$ ve prostaglandin gibi pek çok algojenik madde, periferik nosisepörleri uyararak spinal korda ağrı impulslarının iletilmesine neden olur. Ayrıca, ortama salınan bu kimyasal mediyatörler, kapiller permeabiliteyi etkileyerek ve vazodilatasyona neden olarak, dokuda ödem ve hassasiyete yol açar. Bunun için, nosiseptif ağrı ödem ve hassasiyet ile hatırlanır. Sık karşılaştığımız nosiseptif ağrılı durumlar başlıca, kas-iskelet sistemi bozuklukları, malignite durumları ve post-travmatik patolojilere sekonderdir. ${ }^{[19-21]}$

Nöropatik ağrı ise nosiseptif ağrıdan farklıdır. Nöropatik ağrıda anahtar nokta, somatosensöriyel sistemde lezyon ya da hastalık varlığıdır. Başlıca nöropatik ağrılı durumlar; diyabetik nöropati, postherpetik nevralji, HIV, alkol, postravmatik veya cerrahi sonrası sinir hasarı sonucu gelişen kronik ağrı ve kanserdir. ${ }^{[22-24]}$

Sinir hasarı olduğunda nöropatik ağı ortaya çıkar demiştik. Sinirlerin nasıl çalıştığını gözden geçirecek olursak, nöropatik ağrı durumunda altta yatan mekanizmaları da daha iyi anlamış oluruz. Bu noktada, sinir 
fonksiyonu ile arabanın mekaniği arasında bir benzeşim kurarsak; sodyum kanalları gaz pedalına benzer; presinaptik duyusal nöronda bu kanalın çalışması, elektriksel aktivite üretimine yol açar. ${ }^{[25]}$ Kalsiyum kanalları, arabanın debriyajına yani oluşan gücün aktarımına benzer. Presinaptik duyusal nöronda bu kanalın çalışması, elektriksel aktivite sonucunda uyarılmış nörondan nörotransmitter salınımına yol açar. Salınan nörotransmitterler, postsinaptik duyusal nöronun uyarılmasına yol açar. ${ }^{[26]}$ Potasyum kanalları ise fren pedalına benzer. Postsinaptik duyusal nöronda bu kanalın açılması, nöronda hiperpolarizasyona yol açarak iletiyi durdurur. ${ }^{[27]}$

Nöropatik ağrı durumlarında iyon kanalları arasındaki dengeli çalışma bozulur. Örneğin hasarlı sinir dokusunda sodyum kanal sayısında artış ve kalsiyum kanal hiperaktivitesi ortaya çıkar. Bu yüzden, nöropatik ağrının tedavisinde iyon kanalları ana hedefi oluşturur.

Nöropatik ağrıda, duyusal sinyallerin anormal işlenmesi sonucunda gözlenen çok çeşitli duyusal bozukluklar ortaya çıkar. Bunların başlıcaları Tablo 1'de özetlenmiştir.

Nöropatik ağrıda semptom ve bulguları negatif ve pozitif olarak ikiye ayıracak olursak, başlıca negatif bulgular; dokunma, vibrasyon, ağrı ve sıcaklık duyusunda azalma veya kaybolma şeklindedir. Nöropatik ağrıda pozitif duyusal bulgular ise spontan veya uyarılmış olarak ortaya çıkar. Spontan bulgular sürekli veya aralıklı olabilir. Uyarılmış pozitif duyusal bulgular ise başlıca, allodini ve hiperaljezidir. Bunların yanı sıra nöropatik ağrıda eşlik eden otonomik (terleme ve salivasyonda artış, ortostatik hipotansiyon, mesane ve

Tablo 1. Nöropatik ağrıda duyusal bozukluklar

\begin{tabular}{|c|c|}
\hline İlişkili durum & Klinik özellik \\
\hline Allodini & Ağrısız bir uyaranın ağrılı hissedilmesi \\
\hline Parestezi & $\begin{array}{l}\text { Spontan olarak veya uyarılma sonucunda } \\
\text { ortaya çıkan anormal duyusal algılama }\end{array}$ \\
\hline Dizestezi & $\begin{array}{l}\text { Spontan olarak veya uyarılma sonucunda ortaya } \\
\text { çıkan rahatsız edici anormal duyusal algılama }\end{array}$ \\
\hline Hiperestezi & Duyusal uyarana artmış duyusal hassasiyet \\
\hline Hiperaljezi & Ağrılı bir uyarana karşı artmış ağrı yanıtı \\
\hline Hipoestezi & Duyusal uyarana azalmış duyusal hassasiyet \\
\hline Anestezi & Tüm duyu modalitelerinin kaybı \\
\hline Hipoaljezi & Ağrılı bir stimulusa azalmış ağrı yanıtı \\
\hline Analjezi & Ağrı duyusunun kaybı \\
\hline
\end{tabular}

barsak disfonksiyonu ve erektil disfonksiyon gibi) bulgular da bulunabilir. ${ }^{[28]}$

Bir başka bakış açısıyla, ağrıyı akut ve kronik olarak ikiye ayırabiliriz. Akut ağrı, travma, cerrahi veya doku hasarı sonrası oluşan, analjezik ilaçlarla kontrol altına alınabilen, iyileşme süreci sonunda kaybolan bir bulgudur. Dolayısıyla, akut ağrı koruyucu fonksiyonu nedeniyle canlı için yararlı bir biyolojik uyarandır. Kronik ağrı ise; genellikle üç aydan uzun bir süredir var olan, iyileşme sürecinden bağımsız, beraberinde affektif, bilişsel ve motivasyonel bozuklukların da eşlik ettiği, fonksiyonel azalma ve yaşam kalitesinde bozulmaya yol açan, multimodal tedavi gerektiren bir maladaptif süreç veya bir hastalıktır. Benzer şekilde, kronik ağrıyı da kendi içerisinde kanser ve kanser dışı kronik ağrılar olmak üzere iki gruba ayırabiliriz. ${ }^{[1,29]}$

Kronik ağrının etkilerini geniş kapsamlı düşünmek gerekir; hastalarda anksiyete, mobilitede azalma, iştah bozukluğu, sosyal bozukluklar, depresyon, uyku bozukluğu ve iş hayatında kısıtlamalar gibi pek çok fiziksel ve psikolojik etkilere yol açarak yaşam kalitesini düşürdüğünü hatırlamalıyız. Gerek nosiseptif, gerek nöropatik gerekse de mikst tipteki ağrılar kronikleşebilir. Etkin bir kronik ağrı tedavisi için, kronikleşme sürecinin altında yatan mekanizmaları anlamak önemlidir. ${ }^{[6,23,30]}$

Kronik ağrıda, genellikle nöropatik bir bileşen bulunur ve altta yatan mekanizmalar; yapısı ve fonksiyonları değişmiş duyusal nöronlarda gelişen periferik ve santral sensitizasyonla ilişkili olarak ağrı sinyallerinin iletiminin artmasıdır. Ağrı sinyallerine neden olan uyarıların süresi, kronik ağrı gelişiminde en temel faktördür. Ağrının kronikleşmesini önlemek için, erken ve yeterli akut ağrı tedavisi yaparak sensitizasyon gelişmesini önlememiz gerekmektedir. ${ }^{[31,32]}$

Ağrının kronikleşmesi, bir dizi moleküler ve hücresel süreç içerir. Başlıca, uzamış nörojenik inflamasyon, periferik sensitizasyon ve santral sensitizasyon, ağrı iletim ve işleme süreçlerini değiştirerek sonuçta ağrının algılanma sürecini değiştirir. İnflamasyon uygun şekilde tedavi edilmezse, ortamda kalıcı hale gelen inflamatuvar ve algojenik mediyatörler, sensitizasyona neden olarak nosiseptörler üzerinde kalıcı değişikliklere yol açmaktadır. ${ }^{[4]}$

İnflamatuvar maddeler, nöronal stimülasyonu arttırarak nosiseptörlerin duyarlılaşmasına neden olur. Duyarlılaşmış nosiseptörlerin uyarılma eşikleri düşer; böylece bunlar normal uyaranlara karşı da duyarlı hale gelir. Periferik sensitizasyon süresince afferent nosiseptif nöronlarda ağrı iletimi artar; bu durumun klinik karşılığı hiperaljezidir. ${ }^{[6]}$ 


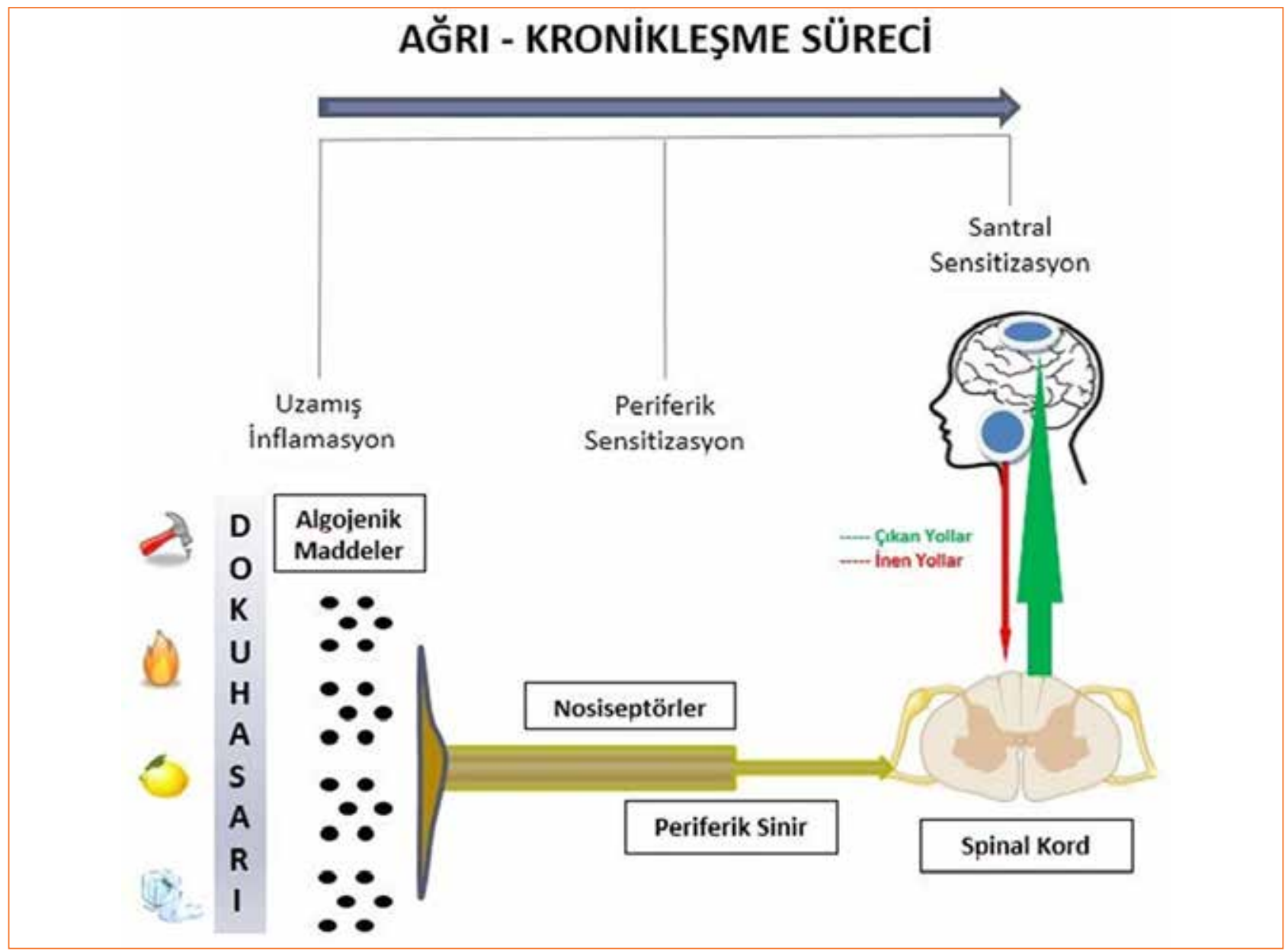

Şekil 4. Ağrı kronikleşme süreci.

Santral sensitizasyon, spinal ve suprasinal nöronların persistan aktivasyonu sonucu kronik ağrıda meydana gelen bir diğer ağrı işleme süreci bozukluğudur. Santral sensitizasyonda, çok sayıda hücresel mekanizma nosiseptif nöronun fonksiyonel durumunda değişikliğe yol açar. Persistan periferik uyarılar, postsinaptik duyusal nöronda normalde glutamata yanıtsız olan NMDA reseptörlerinde uzamış aktivasyon gelişmesine yol açar. Bunun sonucunda, ikinci duyusal nöronda azalmış aktivasyon eşiği, reseptif alanda genişleme ve spontan aktivasyon gelişir ki bu duruma wind-up fenomeni denilmektedir. Santral sensitizasyonun klinik yansımasını, allodini, hiperaljezi ve spontan ağrı duyumunun meydana gelmesiyle görmekteyiz.

Tüm bunların yanı sıra, santral sensitizasyonun geç dönemlerinde ağrıyı kontrol eden inen inhibitör yolaklara karşı ikinci duyusal nöronda duyarsızlık gelişir; bu da medulla spinaliste aşırı uyarılabilme durumuna yol açar. Periferiden küçük bir alandan gelen ağrı sinyalleri, hipersensitize spinal kord nedeniyle amplifiye edilerek üst merkezlere iletilir. Bunun sonucunda, olması gerekenden daha büyük bir alanda ağrı duyulur. Bu ayrıca, limbik yapılara artan uyarım sonucu, korku, anksiyete, uyku bozuklukları ve depresyon gibi komorbid durumların da gelişmesine yol açar. Diğer taraftan, spinal kord düzeyinde; noradrenerjik inhibitör yolaklarda aktivasyon azalması ve güçlü opioderjik etkiden sorunlu olan $\mu$-opioid reseptör sentezinde azalmış ekspresyon sonucu, dorsal boynuz nöronlarında opioderjik etkiye azalmış duyarlılık gelişmektedir. ${ }^{[30,31]}$

Periferik ve santral sistemindeki tüm bu değişikliklerin kombinasyonu sonucunda hipersensitif bir durum oluşmaktadır. Normalde algılanmayan stimuluslar algılanır hale, normalde algılanan duyular ise ağrılı hale gelmektedir (Şekil 4). 
Dünya Sağlık Örgütü (WHO); ağrının şiddetine göre analjeziklerin basamaklı yaklaşımını önermektedir. Buna göre; kronik ağrı hastalarının çok boyutlu yönleri ve altta yatan mekanizmalar dikkate alınmaz. Bu yaklaşım, kronik ağrılı hastalarda uygun bir yaklaşım değildir. Kronik ağrı hastalarında tedavi, ağrının şiddetine göre değil altta yatan mekanizmalara göre yapılmalı; ayrıca, hastanın tedavisinin yönetiminde psikososyal özellikleri de göz önüne alınarak multidisipliner yaklaşım gerekmektedir. ${ }^{[33,34]}$

\section{KAYNAKLAR}

1. WHO Normative Guidelines On Pain Management. Report of a Delphi Study to determine the need for guidelines and to identify the number and topics of guidelines that should be developed by WHO. Report prepared by Prof Neeta Kumar, Consultant. Geneva; 2007.

2. Merskey $\mathrm{H}$, Bogduk N. Classification of Chronic Pain: Descriptions of Chronic Pain Syndromes and Definitions of Pain Terms, 2nd ed. Seattle: IASP Press; 1994.

3. Fine PG, Ashburn MA. Functional Neuroanatomy and ociception. In: Ashburn MA, Rice LJ, editors. The Management of Pain. New York: Churchill Livingstone; 1998. p.1-17.

4. Marchand S. The physiology of pain mechanisms: from the periphery to the brain. Rheum Dis Clin North Am 2008;34(2):285-309. Crossref

5. Heinricher MM, Tavares I, Leith JL, Lumb BM. Descending control of nociception: specificity, recruitment and plasticity. Brain Res Rev 2009;60(1):214-25. Crossref

6. Woolf CJ; American College of Physicians; American Physiological Society. Pain: moving from symptom control toward mechanism-specific pharmacologic management. Ann Intern Med 2004;140(6):441-51.

7. Aydın ON. Ağrı ve ağrı mekanizmalarına güncel bakış. ADÜ Tıp Fakültesi Dergisi 2002;3(2):37-48.

8. Ertekin C. Ağrının nöroanatomisi ve nörofizyolojisi, ağrı ve tedavisi. Yegül i, editör. İzmir: Yapım Matbaacılık; 1993. s.1-18.

9. Nathan PW. Observations on sensory and sympathetic function during intrathecal analgesia. J Neurol Neurosurg Psychiatry 1976;39(2):114-21.

10. Markenson JA. Mechanisms of chronic pain. Am J Med 1996;101(1A):6S-18S.

11. Fundytus ME. Glutamate receptors and nociception: implications for the drug treatment of pain. CNS Drugs 2001;15(1):29-58.

12. Harvey VL, Dickenson $\mathrm{AH}$. Mechanisms of pain in nonmalignant disease. Curr Opin Support Palliat Care 2008;2(2):133-9. Crossref

13. Jasmin L, Wu MV, Ohara PT. GABA puts a stop to pain. Curr Drug Targets CNS Neurol Disord 2004;3(6):487-505.

14. Heavner JE, Willis WD. Pain pathways: Anatomy and physiology. In: Raj PP, editor. Practical Management of Pain, 3rd ed. St Louis: Mosby Inc.; 2000. p.107-45.

15. Gunter J. Neurobiology of Chronic Pelvic Pain. In: Potts JM, editor. Genitourinary Pain and Inflammation: Diagnosis and Management, 1st ed . Humana Press; 2008. p.3-17. Crossref
16. Baranowski AP. Chronic pelvic pain. Best Pract Res Clin Gastroenterol 2009;23(4):593-610. Crossref

17. Bannister K, Bee LA, Dickenson AH. Preclinical and early clinical investigations related to monoaminergic pain modulation. Neurotherapeutics 2009;6(4):703-12. Crossref

18. Şengün İ. Nöropatik Ağrı Mekanizmaları. İçinde: Tan E, editör. Nöropatik Ağrı Kitabı. Türk Nöroloji Derneği; 2009. s.25-46.

19. Botting RM, Botting $\mathrm{JH}$. Pathogenesis and Mechanisms of Inflammation and Pain. Clin Drug Investig 2000;19(Suppl 2):1-7. Crossref

20. Schaible HG, Richter F, Ebersberger A, Boettger MK, Vanegas $H$, Natura G, Vazquez E, Segond von Banchet G. Joint pain. Exp Brain Res 2009;196(1):153-62. Crossref

21. Davis MP, Walsh D. Epidemiology of cancer pain and factors influencing poor pain control. Am J Hosp Palliat Care 2004;21(2):137-42.

22. Geber C, Baumgärtner $U$, Schwab R, Müller H, Stoeter P, Dieterich M, Sommer C, Birklein F, Treede RD. Revised definition of neuropathic pain and its grading system: an open case series illustrating its use in clinical practice. Am J Med 2009;122(10 Suppl):S3-12. Crossref

23. Woolf CJ, Mannion RJ. Neuropathic pain: aetiology, symptoms, mechanisms, and management. Lancet 1999;353(9168):1959-64.

24. Campbell JN, Meyer RA. Mechanisms of neuropathic pain. Neuron 2006;52(1):77-92.

25. Hargus NJ, Patel MK. Voltage-gated $\mathrm{Na}+$ channels in neuropathic pain. Expert Opin Investig Drugs 2007;16(5):635-46.

26. Todorovic SM, Jevtovic-Todorovic V. The role of T-type calcium channels in peripheral and central pain processing. CNS Neurol Disord Drug Targets 2006;5(6):639-53.

27. Munro G, Dalby-Brown W. Kv7 (KCNQ) channel modulators and neuropathic pain. J Med Chem 2007;50(11):2576-82.

28. Baron R. Mechanisms of disease: neuropathic pain -a clinical perspective. Nat Clin Pract Neurol 2006;2(2):95-106.

29. Woolf CJ, Max MB. Mechanism-based pain diagnosis: issues for analgesic drug development. Anesthesiology 2001;95(1):241-9.

30. Costigan M, Scholz J, Woolf CJ. Neuropathic pain: a maladaptive response of the nervous system to damage. Annu Rev Neurosci 2009;32:1-32. Crossref

31. Latremoliere A, Woolf CJ. Central sensitization: a generator of pain hypersensitivity by central neural plasticity. J Pain 2009;10(9):895-926. Crossref

32. Rothstein D, Zenz M. Chronic pain management. Internist (Berl) 2009;50(9):1161-8. Crossref

33. Vargas-Schaffer $G$. Is the WHO analgesic ladder still valid? Twenty-four years of experience. Can Fam Physician 2010;56(6):514-7, e202-5.

34. Dworkin RH, O'Connor AB, Audette J, Baron R, Gourlay GK, Haanpää ML, Kent JL, Krane EJ, Lebel AA, Levy RM, Mackey SC, Mayer J, Miaskowski C, Raja SN, Rice AS, Schmader KE, Stacey B, Stanos S, Treede RD, Turk DC, Walco GA, Wells CD. Recommendations for the pharmacological management of neuropathic pain: an overview and literature update. Mayo Clin Proc 2010;85(3 Suppl):S3-14. Crossref 